\title{
Synapses and Memory Storage
}

\author{
Mark Mayford ${ }^{1}$, Steven A. Siegelbaum ${ }^{2}$, and Eric R. Kandel ${ }^{2}$ \\ ${ }^{1}$ The Scripps Research Institute, Department of Cell Biology, La Jolla, California 92037 \\ ${ }^{2}$ Columbia University, Kavli Institute for Brain Science, Howard Hughes Medical Institute, \\ Department of Neuroscience, New York, New York 10032 \\ Correspondence: erk5@columbia.edu
}

\begin{abstract}
The synapse is the functional unit of the brain. During the last several decades we have acquired a great deal of information on its structure, molecular components, and physiological function. It is clear that synapses are morphologically and molecularly diverse and that this diversity is recruited to different functions. One of the most intriguing findings is that the size of the synaptic response in not invariant, but can be altered by a variety of homoand heterosynaptic factors such as past patterns of use or modulatory neurotransmitters. Perhaps the most difficult challenge in neuroscience is to design experiments that reveal how these basic building blocks of the brain are put together and how they are regulated to mediate the information flow through neural circuits that is necessary to produce complex behaviors and store memories. In this review we will focus on studies that attempt to uncover the role of synaptic plasticity in the regulation of whole-animal behavior by learning and memory.
\end{abstract}

$T_{\mathrm{in}}^{\mathrm{h}}$ he idea that learning results from changes in the strength of the synapse was first suggested by Santiago Ramon y Cajal (1894) based on insights from his anatomical studies. That modulation of synaptic connectivity is a critical mechanism of learning was incorporated into more refined models by Hebb in the 1940s and 1950s. The experimental investigation of these intriguing conjectures required the development of behavioral systems in which one could examine changes in the neuronal components of a specific behavior during or after the modification of that behavior with learning (Kandel and Spencer 1968).

\section{SYNAPTIC CHANGES WITH LEARNING}

\section{Procedural Memory in Simple Systems}

The first attempts to identify neuronal changes that underlie learning and memory used simple forms of procedural memory such as habituation, sensitization, and classical conditioning. From 1969 to 1979 several useful model systems emerged: the flexion reflex of cats (Spencer et al. 1966); the eye-blink response of rabbits (Thompson et al. 1983); and a variety of reflex behaviors in invertebrate systems, including the gill-withdrawal reflex of Aplysia (Kandel and Tauc 1963), the escape reflex of Tritonia

Editors: Morgan Sheng, Bernardo Sabatini, and Thomas C. Südhof

Additional Perspectives on The Synapse available at www.cshperspectives.org

Copyright (C) 2012 Cold Spring Harbor Laboratory Press; all rights reserved; doi: 10.1101/cshperspect.a005751

Cite this article as Cold Spring Harb Perspect Biol 2012;4:a005751 
M. Mayford et al.

(Willows and Hoyle 1969), and various behavioral modifications in Hermissenda (Alkon 1974), Pleurobranchaea (Mpitsos and Davis 1973), Limax (Gelperin 1975), crayfish (Krasne 1969), and honeybees (Menzel and Erber 1978). These preparations were chosen for the limited number of neurons (or neuronal types) that participated in the behavior. This reductionist approach allowed the specific circuitry that controlled the behavior to be defined and examined for modification following learning. The studies were aimed at pinpointing the sites within a neural circuit that are modified by learning and used for memory storage, and for identifying the cellular basis for those changes.

By allowing electrophysiological recording from individual neurons that are readily identifiable from animal to animal and that form part of a simple behavioral circuit, these systems provided the first experimental insight into the cellular mechanisms of memory. One mechanism for learning and short-term memory, evident in both the gill-withdrawal reflex of Aplysia and in the tail-flick response of crayfish, is a change in synaptic strength brought about by modulating the release of transmitter. A decrease in transmitter release is associated with short-term habituation, whereas an increase in transmitter release occurs during short-term dishabituation and sensitization (Castellucci et al. 1970, 1974,
1976; Zucker et al. 1971; for early reviews, see Kandel 1976; Carew and Sahley 1986). The plasticity occurred at the sensory neuron inputs onto the motor neurons that control the reflex response and thus directly modulate its magnitude. These studies provided the first evidence for the idea that behavioral memory is mediated by plasticity in the synaptic connections between neurons that participate in the behavior.

Cell biological studies of the connections between the sensory and motor neurons of the gill-withdrawal reflex in Aplysia revealed a biochemical mechanism for the short-term increase in transmitter release produced by sensitization (Fig. 1) (Kandel 2001). A single noxious (sensitizing) stimulus to the tail leads to the activation of three known classes of modulatory neurons. The most important releases serotonin, which acts to increase the level of cAMP in the sensory neurons. This in turn activates the cAMP-dependent protein kinase (PKA), which enhances synaptic transmission. Injecting cAMP or the catalytic subunit of PKA directly into the sensory neurons is sufficient to enhance learning-related transmitter release (Brunelli et al. 1976; Castellucci et al. 1976).

Studies of the gill-withdrawal reflex also revealed that even elementary forms of learning have distinct short- and long-term stages of memory storage. Whereas one training trial

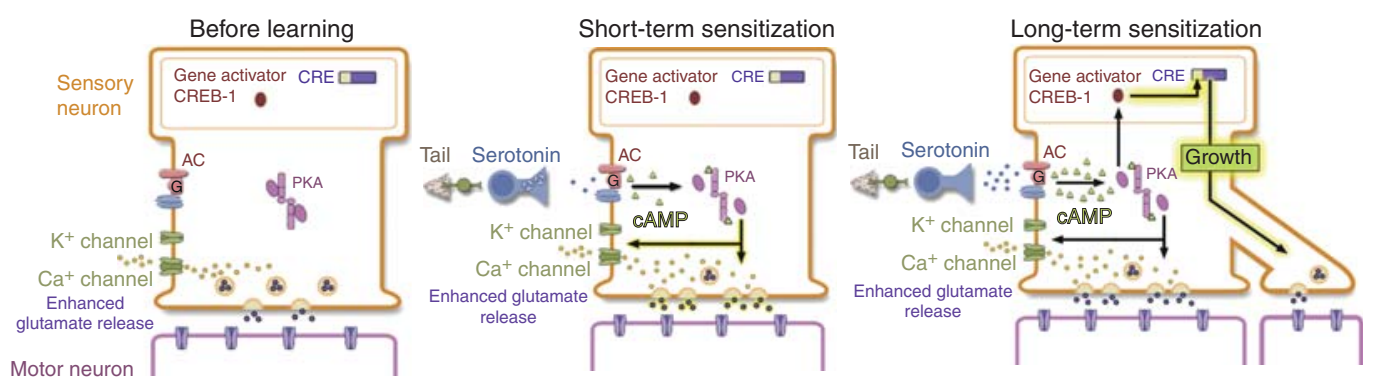

Figure 1. Short-term and long-term sensitization of the gill-withdrawal refex in Aplysia involves posttranslational modifications and alterations in protein synthesis. (Left) The gill-withdrawal circuit. A tactile stimulus to the siphon causes a sensory neuron to release glutamate to excite a motor neuron. (Center) A shock to the tail causes serotonin release from interneurons. This activates a stimulatory $G$ protein $(G)$, which activates adenylyl cyclase (AC), leading to production of cAMP and PKA-dependent phosphorylation of different substrates, including $\mathrm{K}^{+}$and $\mathrm{Ca}^{2+}$ channels, which enhances glutamate release from the sensory neuron terminals. (Right) Repeated shocks to the tail elicit a persistent increase in cAMP, leading to altered gene transcription and protein synthesis. This leads to growth of new synapses. 
gives rise to a short-term memory lasting minutes, repeated spaced training gives rise to longterm memory lasting days to weeks (Carew et al. 1972; Pinsker et al. 1973). These behavioral stages have a parallel in the stages of the underlying synaptic plasticity-a short-term form lasting minutes to hours and a long-term form lasting days to weeks (Carew et al. 1972; Castellucci et al. 1978). In addition to the immediate and short-term changes in synaptic function with learning, profound structural changes accompany the storage of long-term memory in both habituation and sensitization of the gill-withdrawal reflex. The sensory neurons from habituated animals retract some of their presynaptic terminals so that they make fewer connections with motor neurons and interneurons than do sensory neurons from control animals (Bailey and Chen 1983, 1988a). In contrast, following long-term sensitization the number of presynaptic terminals of the sensory neurons increases more than twofold (Bailey and Chen 1983, 1988a). This learning-induced synaptic growth is not limited to sensory neurons. The dendrites of the postsynaptic motor neurons also grow and remodel to accommodate the additional sensory input (Bailey and Chen 1988b). These results show that clear structural changes in both the pre- and postsynaptic cells can accompany even elementary forms of learning and memory in Aplysia and serve to increase or decrease the total number of functional synaptic connections critically involved in the behavioral modification.

Together, these early cellular studies of simple behaviors provided direct evidence supporting Ramon y Cajal's suggestion that synaptic connections between neurons are not immutable but can be modified by learning, and that those anatomical modifications serve as elementary components of memory storage (Bailey and Kandel 1993). In the gill-withdrawal reflex, changes in synaptic strength occurred not only in the connections between sensory neurons and their motor cells but also in the connections between the sensory neurons and the interneurons (Hawkins et al. 1981; Frost and Kandel 1995). Thus, memory storage, even for elementary procedural memories, is distributed among multiple sites. The studies showed further that a single synaptic connection is capable of being modified in opposite ways by different forms of learning, and for different periods of time ranging from minutes to weeks for different stages of memory.

Studies of memory in invertebrates also delineated a family of psychological concepts (Hawkins and Kandel 1984) paralleling those first described in vertebrates by the classical behaviorists (Pavlov and Thorndike) and their modern counterparts (Kamin, Rescorla, and Wagner). These concepts include the distinction between various forms of associative and nonassociative learning and the insight that contingency - that the conditioned stimulus (CS), in associative learning, is predictive of the unconditional stimulus (US) - is more critical for learning than mere contiguity; this is the CS that must precede the US by a short interval of time (see, for example, Rescorla and Wagner 1972). Such psychological concepts, which had been inferred from purely behavioral studies, could be explained in terms of their underlying cellular and molecular mechanisms. For example, the finding that the same sensory-tomotor neuron synapses that mediate the gillwithdrawal reflex are the cellular substrates of learning and memory illustrates that procedural memory storage does not depend on specialized, superimposed memory neurons whose only function is to store rather than process information. Rather, the capability for simple procedural memory storage is built into the neural architecture of the reflex pathway (Castellucci and Kandel 1976).

\section{Declarative Memory and the Hippocampus}

In the mammalian brain two major early threads of research were critical in moving the study of memory forward to the point that the question of cellular and synaptic mechanisms could begin to be addressed. The first thread was anatomical and revealed a remarkable localization of memory function in the mammalian brain. Studies of patients with damage to the medial temporal lobes revealed that there are two major memory systems in the brain: declarative 
M. Mayford et al.

(explicit) and procedural (implicit or nondeclarative). Declarative memory, a memory for facts and events-for people, places, and objects-requires the medial temporal lobe and in particular the hippocampus (Scoville and Milner 1957; Squire 1992; Schacter and Tulving 1994). In contrast, procedural memory, a memory for perceptual and motor skills also evident in invertebrate animals, involves a number of brain systems depending on the specific type of learning and in the most elementary instances uses simple reflex pathways themselves, as discussed above for simple systems. Although these seminal studies identified important classifications of memory and helped to solidify the notion of functional localization at a broad anatomical level, they did not provide insight into the mechanisms acting at the finer level of the individual neuron or synapse. This next step forward was made in rodent studies, in which the hippocampus plays a similar role in declarative types of memory, such as memory for place.

In 1971 recordings of single unit firing in the hippocampus of awake, freely moving rats revealed that neurons in the hippocampus register information not about a single sensory modality — sight, sound, touch, or pain-but about the space surrounding the animal, a feat that depends on information from several senses (O'Keefe and Dostrovsky 1971). These cells, referred to as "place cells," fire selectively when an animal enters a particular area of the spatial environment. Based on these findings, O'Keefe and Nadel (1978) suggested that the hippocampus contains a cognitive map of the external environment that the animal uses to navigate. These studies helped to define the role of the hippocampus in declarative memory as a multimodal integrator and mapmaker. Although spatial location is a strong component of this hippocampal map, the human lesion studies and work from Howard Eichenbaum in rodents suggest that it may be a more general integrator of memory-specific associations (Squire and Stark 2004)

Nearly contemporaneous with the discovery of place cells, the synaptic responses in the hippocampus were found to display plasticity with several features advantageous for memory storage (Bliss and Lømo 1973). Stimulation with a high-frequency train of action potentials was shown to produce a prolonged strengthening of synaptic transmission in all three of the major hippocampal pathways. This long-term potentiation (LTP), which is discussed in detail in the article by Lüscher and Malenka (2012) in this collection, has several forms that differ in molecular mechanism and duration (Fig. 2). In both the perforant path synapses from entorhinal cortex to dentate gyrus and Schaffer collateral synapses from CA3 to CA1 pyramidal neurons, LTP follows learning rules first postulated by Hebb. It requires that presynaptic activity be closely followed by postsynaptic activity. In the mossy fiber pathway, LTP does not follow Hebb's rules; it requires only presynaptic activity with no coincident postsynaptic activity (Bliss and Collingridge 1993).

The Hebbian form of LTP has been the focus of intense interest as it became clear that it possessed many other features useful for a synaptic mechanism for certain forms of learning. These critical features of LTP are synapse specificity, cooperativity, and associativity. LTP is synapse specific in that it is only induced at synapses that are activated by the tetanic stimulation; neighboring synapses that are not active do not undergo potentiation. LTP is cooperative because multiple inputs must be activated simultaneously to produce sufficient postsynaptic depolarization to induce LTP. Finally, LTP is associative because when a weak input that is normally insufficient to induce LTP is paired with a strong input, the weak input will now become potentiated. These features can largely be explained by the behavior of the $N$-methyl-Daspartate (NMDA)-type glutamate receptor, whose activation is critical for the induction of the Hebbian form of LTP (see Lüscher and Malenka 2012). Unlike most neurotransmitter receptors that respond simply to the presence or absence of their cognate transmitter in the synaptic cleft, the NMDA receptor is also sensitive to the state of the postsynaptic membrane in which it resides. Under normal resting conditions a $\mathrm{Mg}^{2+}$ ion present in the NMDA receptor pore blocks ion flux. However, this $\mathrm{Mg}^{2+}$ 


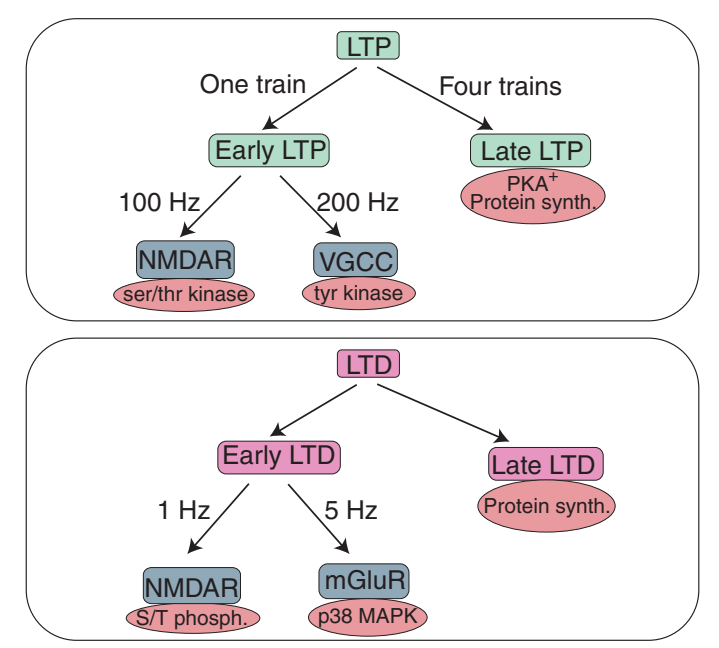

Figure 2. Multiple forms of long-term synaptic plasticity may contribute to learning and memory. (Top) A single train of high-frequency tetanic synaptic stimulation can produce forms of long-term potentiation (LTP) of synaptic transmission lasting 1-2 h. This early LTP (E-LTP) does not require changes in transcription or translation. Different patterns of tetanic stimulation can recruit distinct forms of E-LTP that differ in molecular mechanism and site of expression. Multiple trains of tetanic synaptic stimulation can induce a more persistent form of synaptic plasticity that can persist for many hours. This late LTP (L-LTP) requires altered gene expression, activation of PKA, and new protein synthesis. (Bottom) Weaker forms of synaptic activity can lead to a long-term depression of synaptic transmission (LTD). Different patterns of synaptic stimulation recruit distinct forms of LTD through differing signaling pathways.

blockade can be relieved by depolarization of the postsynaptic membrane, which expels the blocking ion through electrostatic repulsion. Thus, NMDA receptors are only active when there is both glutamate present because of presynaptic activity and the postsynaptic neuron is substantially depolarized. LTP is therefore produced only at synapses from a given presynaptic neuron that are active (leading to glutamate release) and impinge on a postsynaptic neuron that receives sufficient concurrently active inputs (associativity and cooperativity) to produce enough depolarization to relieve $\mathrm{Mg}^{2+}$ blockade of the NMDA receptor. As a result, LTP conforms to the type of learning rule Hebb suggested: "When an axon of cell A is near enough to excite cell $B$ and repeatedly or persistently takes part in firing it, some growth process or metabolic change takes place in one or both cells such that A's efficiency, as one of the cells firing B, is increased."

Activation of NMDA receptors produces an influx of postsynaptic $\mathrm{Ca}^{2+}$ that is critical to the induction of LTP (Lynch et al. 1983; Malenka et al. 1988). In addition to LTP, which is routinely induced at hippocampal synapses by brief high-frequency $(100-\mathrm{Hz})$ stimuli, hippocampal synapses also show a form of long-lasting synaptic depression, or LTD, with prolonged lowfrequency stimulation. Surprisingly, this form of plasticity also requires activation of NMDA receptors and postsynaptic $\mathrm{Ca}^{2+}$. The direction of the synaptic change likely depends on the magnitude and dynamics of the postsynaptic $\mathrm{Ca}^{2+}$ signal, as well as on the current state of the synapse, for example, whether it has been recently potentiated.

LTP and LTD were identified and have been studied primarily using artificial electrical stimulation that activates large numbers of fibers in a manner that is unlikely to occur naturally. The discovery of a spike-time-dependent form of synaptic plasticity (STDP) (Markram et al. 1997; Magee and Johnston 1997) was an important advance in providing a physiologically plausible manipulation that induced synaptic 
M. Mayford et al.

plasticity. In STDP a synapse becomes potentiated if a postsynaptic spike follows presynaptic release, whereas the synapse becomes depressed if the postsynaptic spike precedes release. The plasticity occurs within a tight time window such that release and spike activity offset by more than $40 \mathrm{~ms}$ produce no synaptic change. STDP is also NMDA receptor dependent and is likely to incorporate some of the molecular mechanisms of LTP and LTD studied using less physiological stimuli, although there are clearly some important differences, as we shall see below.

Although the properties of NMDA-dependent synaptic plasticity are intriguing and provide a straightforward cellular mechanism for forming learned associations, it has been significantly more difficult to provide direct experimental links between LTP and behavior. In 1986 pharmacological studies made the first connection of LTP to spatial memory by showing that NMDA receptors must be activated to form this type of memory in the rat. When NMDA receptors are blocked pharmacologically, not only is LTP blocked, but the animal can no longer form spatial memories that are dependent on the hippocampus. This was shown using the Morris water maze, in which an animal must integrate multiple visual cues to form a spatial memory of the location of a platform submerged below the surface of a water bath (Morris et al. 1986). Importantly, blockade of the NMDA receptors does not impair the ability of an animal to learn to swim to the platform when it is visible, a task that does not require the hippocampus.

Similarly, the pharmacological blockade of NMDA receptors has been found to alter the stability of the place fields of hippocampal place cells (Kentros et al. 1998). When animals are placed in the same environment two days in a row, they activate substantially the same ensemble of hippocampal place cells whose place fields are similar in position and size on each day. This is consistent with the idea that these cells encode a stable map of the environment. However, if an NMDA blocker is administered during the formation of this place map, then the place-cellfiring pattern is not stable over $24 \mathrm{~h}$.

These results provide a causal link between NMDA receptor function, long-term place cell stability, and long-term spatial memory. It is tempting to think that these effects are linked by a causal requirement for LTP or LTD in these processes; however, a number of caveats should be kept in mind. For example, certain genetic manipulations that disrupt hippocampal LTP do not impair forms of memory believed to require the hippocampus (e.g., Zamanillo et al. 1999). Conversely, manipulations that do not alter hippocampal LTP can disrupt spatial learning (Shimshek et al. 2006).

One of the most difficult problems in linking synaptic plasticity mechanisms to behavior in declarative memory is the sparse and distributed nature of the circuits. How the various neural representations of the environment are modified with learning, the location of the critical sites of plasticity, and how these modified circuits are recruited to alter motor behavior in a memory test are still largely unclear. This makes interpreting the effects of a single type of pharmacological manipulation quite difficult. One approach that has been taken in both simple and complex models is to apply molecular and genetic approaches to provide a richer understanding of the underlying mechanisms of plasticity and to use the tools generated to probe the links to behavior.

\section{Procedural Fear Memory in the Mammalian Amygdala}

Some of the strongest evidence linking learning and memory to LTP comes from experiments focused on the amygdala, which is essential for both instinctive and learned fear (Davis et al. 1994; LeDoux 1995, 1996). When an animal is given a shock to the foot paired with a tone-a classical conditioning paradigm - the animal exhibits a learned fear response by freezing in response to the tone alone. This form of learning is known to involve the amygdala, a region of the brain that receives direct auditory information from the thalamus and processed information from neocortex, and which provides an output to the hypothalamus that regulates autonomic fear responses. Neurons in isolated slices of amygdala undergo LTP in response to tetanic stimulation protocols similar to those 
used in the hippocampus. Importantly, behavioral pairing of a tone and shock, which induces fear learning, also potentiates synaptic responses in the amygdala to auditory stimuli in vivo (Rogan et al. 1997). Following fear learning the synaptic response to electrical stimulation of auditory inputs in isolated amygdala slices is also enhanced (McKernan and Shinnick-Gallagher 1997). Moreover, this synaptic enhancement must be closely related to LTP because behavioral fear conditioning occludes the ability to induce LTP in isolated amygdala slices in response to high-frequency stimulation (Tvsetkov et al. 2002).

\section{SYNAPTICAND MOLECULAR MECHANISMS OF PLASTICITY AND LEARNING}

\section{Procedural Memory in Invertebrates}

Molecular biology revealed a remarkable conservation of mechanism underlying short-term memory among different animals. In 1974 Seymour Benzer and his students discovered that Drosophila can learn fear and that mutations in single genes interfere with short-term memory. Flies with such mutations do not respond to classical conditioning of fear or to sensitization, suggesting that the two types of learning have some genes in common (Quinn et al. 1974; Dudai et al. 1976). Identification of the causal mutations in the fly revealed that they represented one or another component of the cAMP pathway, the same pathway underlying sensitization and classical conditioning in Aplysia (Byers et al. 1981). These early studies that pointed to the central role of cAMP signaling examined short-term memory lasting only a few minutes. The next step was to ask how the short-term changes become stabilized to last days or years.

The first clue to how short-term memory is switched to long-term memory came when Louis Flexner observed that the formation of long-term memory requires the synthesis of new proteins (Flexner et al. 1963). Subsequent work in Aplysia (Dash et al. 1990; Bacskai et al. 1993; Martin et al. 1997; Alberini et al. 1994; Hegde et al. 1997; for review, see Kandel 2001) and Drosophila (Dudai et al. 1976; Duerr and
Quinn 1982; Drain et al. 1991; for review, see Waddell and Quinn 2001) showed that with repeated training PKA moves from the synapse to the nucleus of the cell, where it activates the transcription factor cAMP response element binding protein-1 (CREB-1). CREB-1 acts on downstream genes to activate the synthesis of protein and stimulate the growth of new synaptic connections.

Further studies in Aplysia and in the fly revealed the surprising finding that the switch to long-term synaptic change and the growth of new synaptic connections is constrained by memory suppressor genes (see Abel et al. 1998). One important constraint on the growth of new synaptic connections is CREB-2 (Yin et al. 1994; Bartsch et al. 1995), which when overexpressed blocks long-term synaptic facilitation in Aplysia. When CREB-2 is removed, a single exposure to serotonin, which normally produces an increase in synaptic strength lasting only minutes, will increase synaptic strength for days and induce the growth of new synaptic connections.

\section{Declarative Memory}

Molecular and pharmacological studies in hippocampal slice preparations have identified some of the key signaling events that are triggered by $\mathrm{Ca}^{2+}$ influx through the NMDA receptors during the induction of LTP (Fig. 3). The initial $\mathrm{Ca}^{2+}$ signal activates directly or indirectly at least three critical protein kinases in the postsynaptic neuron: (1) calcium calmodulin-dependent kinase II (CaMKII) (Malenka et al. 1989; Malinow et al. 1989); (2) protein kinase C (PKC) (Routenberg 1986; Malinow et al. 1988); and (3) the tyrosine kinase Fyn (O'Dell et al. 1991; Grant et al. 1992). These findings provided a catalog of targets for manipulation using advances in mouse genetics that allowed for the selective deletion or knockout of individual genes in the whole animal. The general strategy was to delete a gene critical for LTP and to then examine both synaptic plasticity and behavioral learning and memory in the same animal to test the idea that LTP is a key molecular event important for memory storage. 
M. Mayford et al.

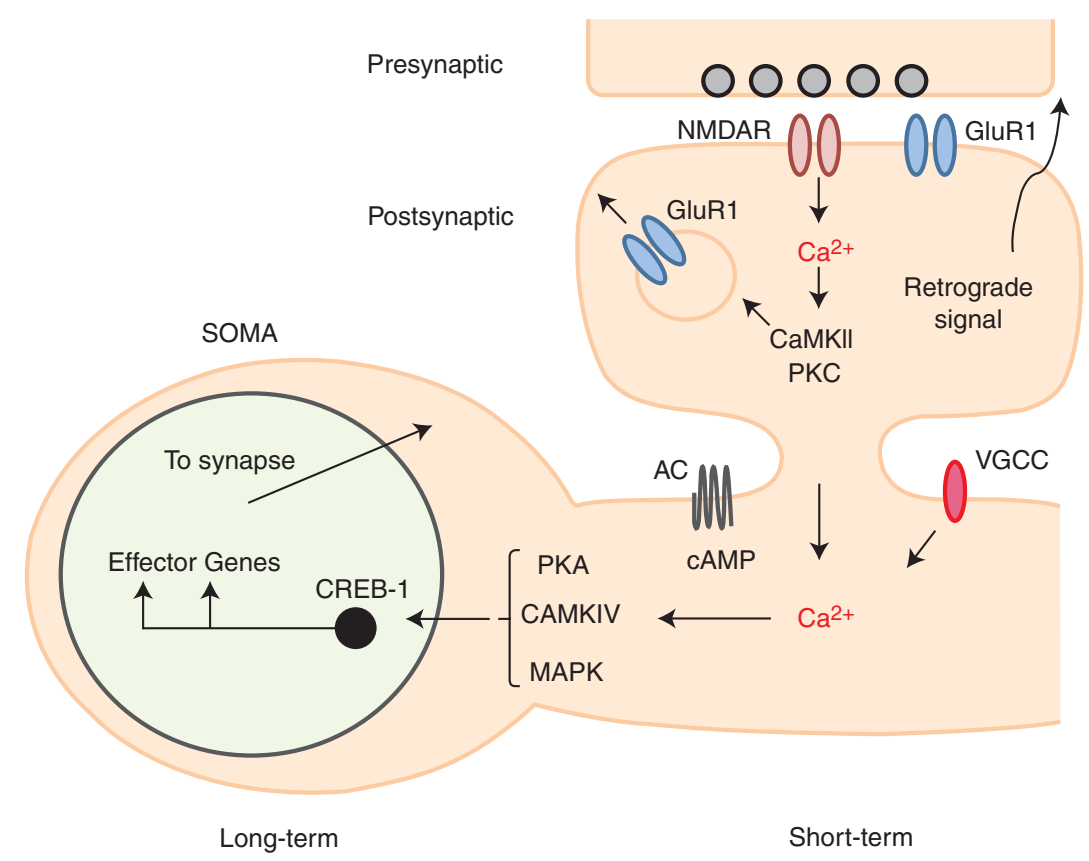

Figure 3. Molecular mechanisms for induction of LTP and memory. These basic signaling pathways have been implicated in both NMDAR-dependent LTP and behavioral learning. Short-term plasticity (lasting several hours) is produced by NMDAR-dependent $\mathrm{Ca}^{2+}$ signaling to protein kinases and the recruitment of new glutamate receptors to the synapse. Long-term plasticity (lasting days) requires CREB-dependent gene activation in the nucleus by the action of multiple protein kinases. Long-term plasticity and memory also requires synthesis of a constitutively active isoform of PKC.

The first set of studies applied these techniques to examine the importance of the $\alpha$ subunit of CaMKII and the tyrosine kinase Fyn. Genetically altered mice lacking either of these kinases were viable and survived to adulthood. However, in each line of mutant mice hippocampal LTP and spatial memory were impaired. These results extended the link between hippocampal synaptic plasticity and memory, first established pharmacologically with NMDA receptor blockers, and outlined a genetic approach for exploring the mechanisms of synaptic and behavioral plasticity. Genetics is the gold standard for determining molecular function in modern biology, and its application to complex questions of neurophysiology and behavior in the mammalian brain opened up a myriad of molecular questions that were previously inaccessible. However, it soon became clear that the approach suffered a number of drawbacks for the study of circuits and behavior that have stimulated several important technical refinements.

A major question regarding the molecular mechanism of LTP is whether it is expressed presynaptically, involving an increase in glutamate release; postsynaptically, depending on an increase in the postsynaptic response to glutamate; or through a coordinated change in presynaptic and postsynaptic properties. A number of apparently contradictory results have been reported in the literature over the past 30 years. However, in our view much of the controversy results from the fact that neurons can express multiple forms of LTP that may differ in their synaptic locus, molecular mechanisms, timescale, and role in learning and memory (Fig. 2).

The controversy dates back to some of the earliest studies of LTP. Measurements of radiolabeled glutamate binding to hippocampal membranes indicated that LTP was postsynaptic, caused by an increase in the number of 
postsynaptic glutamate receptors (Lynch et al. 1982). At the same time another study concluded that LTP was presynaptic, based on the finding of increased levels of extracellular glutamate following induction of LTP (Dolphin et al. 1982). The interpretation of such early studies was complicated by the fact that they did not directly assess synaptic function. Rather, it was the finding that LTP in the Schaffer collateral pathway is associated with a selective increase in the AMPA-type receptor component of the excitatory postsynaptic potential with little change in the NMDA-type receptor component that provided the first evidence that LTP at this synapse is both initiated and expressed postsynaptically (Kauer et al. 1988). Later it was found that the increase in response of the AMPA receptors to glutamate during LTP is attributable to the rapid insertion of new clusters of receptors in the postsynaptic membrane from a pool of intracellular receptors stored in recycling endosomes (Carroll et al. 1999; Shi et al. 1999; Park et al. 2004; Nicoll et al. 2006). Other studies, however, have implicated additional presynaptic changes following induction of Schaffer collateral LTP (Bolshakov and Siegelbaum 1994; Zakharenko et al. 2001; Emptage et al. 2003; Enoki et al. 2009). As nearly all studies of Schaffer collateral LTP indicate that its induction requires $\mathrm{Ca}^{2+}$ influx into the postsynaptic cell, the finding that LTP may involve an increase in transmitter release implicates the need for one or more retrograde messengers that are released from the postsynaptic cell to enhance release from the presynaptic cell. As discussed below, whether LTP is presynaptic or postsynaptic (or both) likely depends on the frequency or pattern of stimulation used to induce plasticity.

Changes in presynaptic function associated with LTP can be assayed selectively by measuring the rate of release of a fluorescent dye, FM 143 , from synaptic vesicles in the presynaptic terminals when the vesicles release their contents by exocytosis in response to presynaptic stimulation (Ryan et al. 1996). When LTP is induced using a $50-\mathrm{Hz}$ tetanic stimulation, there is no change in the rate of dye release in response to presynaptic action potentials, suggesting that the expression of $50-\mathrm{Hz}$ LTP is purely postsyn- aptic. However, when LTP is induced using stronger $200-\mathrm{Hz}$ or theta burst stimulation protocols, there is a marked increase in the rate of dye release, suggesting an enhanced presynaptic function (Zakharenko et al. 2001) that appears to develop more slowly than the enhancement in AMPA receptor response (Bayazitov et al. 2007). The presynaptic and postsynaptic forms of LTP also show a differential dependence on NMDA receptors. Whereas $50-\mathrm{Hz}$ LTP is fully blocked by the NMDA receptor antagonist APV, $200-\mathrm{Hz}$ and theta burst LTP recruit an NMDA receptor-independent form of LTP that requires activation of L-type voltage-gated $\mathrm{Ca}^{2+}$ channels (Grover and Teyler 1990; Zahkarenko et al. 2001). Genetic evidence for the existence of distinct presynaptic and postsynaptic loci of LTP has been provided by studies of AMPA receptor- and brain-derived neurotrophic factor (BDNF)-knockout mice.

The GluR1 (GluRA) AMPA receptor subunit is important for the activity-dependent postsynaptic insertion of AMPA receptors with LTP. Knockout mice carrying a deletion in GluR1 show a severe deficit in "standard" NMDA-dependent LTP induced by high-frequency stimulation, as might be expected from previous studies. Surprisingly, these mice were not impaired in long-term spatial memory as seen with previous knockouts or NMDA receptor antagonists that blocked LTP (Zamanillo et al. 1999). Subsequent studies showed that not all forms of LTP were impaired in these mice; for example, a component of theta burst LTP was spared (Hoffman et al. 2002). Moreover, not all spatial learning was intact; a short-term form of spatial working memory was impaired in the knockout animals (Reisel et al. 2002).

A line of mice in which the BDNF gene was selectively deleted in the forebrain shows relatively normal LTP in response to a $50-\mathrm{Hz}$ tetanic stimulus (Zakharenko et al. 2003). However, these mice have a significant reduction in LTP in response to $200-\mathrm{Hz}$ or theta burst tetanic stimulation. Moreover, the ability of these strong LTP protocols to produce a presynaptic enhancement in the rate of FM 1-43 release is completely blocked in the mutant mice. These data support the view for separable components 
M. Mayford et al.

of presynaptic and postsynaptic LTP that can be differentially recruited by distinct patterns of physiological activity. Interestingly, whereas a reduction in NMDA receptor-dependent LTP is observed as animals age, and is correlated with an age-related decline in memory, older animals show an increase in L-type $\mathrm{Ca}^{2+}$ channel-dependent LTP (Shankar et al. 1998). Moreover, L-type $\mathrm{Ca}^{2+}$ channel antagonists improve memory in older animals (Deyo et al. 1989).

Clearly the relationship between LTP and memory is more complex than a simple 1:1 correspondence. Different forms of LTP have different underlying molecular mechanisms and different roles in behavior that we are just beginning to unravel (e.g., Woodside et al. 2004).

\section{Long-Term Memory}

Procedural and declarative memories differ dramatically. They use a different logic (unconscious vs. conscious recall) and they are stored in different areas of the brain. Nevertheless, these two disparate memory processes share several molecular steps and an overall molecular logic. Both are created in at least two stages: one that does not require the synthesis of new proteins and one that does. In both, short-term memory involves covalent modification of preexisting proteins and changes in the strength of preexisting synaptic connections, whereas long-term memory requires the synthesis of new proteins and the growth of new connections. Moreover, both forms of memory use PKA, mitogen-activated protein kinase (MAPK), CREB-1, and CREB-2 signaling pathways to convert short-term to longterm memory. Finally, both forms appear to use morphological changes at synapses to stabilize long-term memory (Bailey et al. 2008).

Long-term potentiation in the hippocampus proved to have both early and late phases, much as long-term synaptic facilitation in Aplysia does. One train of stimuli produces the early phase (E-LTP), which lasts $1-3 \mathrm{~h}$ and does not require protein synthesis. Four or more trains induce the late phase (L-LTP), which lasts at least $24 \mathrm{~h}$, requires protein synthesis, and is activated by PKA (Frey et al. 1993; Abel et al. 1997). The role of this L-LTP has been investi- gated genetically using mice that express a mutant gene that blocks the catalytic subunit of PKA, or that carry an inhibitory mutation in the CREB-1 gene. Both lines of mice have a serious defect in long-term spatial memory and both have roughly similar defects in LTP. The early phase is normal but the late phase is blocked, providing evidence linking the phases of LTP to the phases of memory storage (Silva et al. 1992a,b; Bourtchouladze et al. 1994; Huang et al. 1995; Abel et al. 1997). Finally, an intermediate phase of LTP that requires PKA but not new protein synthesis can be induced by two trains of stimuli (Winder et al. 1998). Theoretical studies indicate that these multiple components of plasticity are necessary to generate long-lasting memories in the face of ongoing synaptic plasticity (Fusi et al. 2005).

\section{Procedural Memory in Vertebrates}

We now have a good understanding of the neural circuit and molecular mechanisms underlying learned fear and of the role of synaptic plasticity in fear memory, thanks to the work of Joseph LeDoux, Michael Davis, Michael Fanselow, and James McGaugh. Pairing of a tone with a foot shock leads to a conditioned fear response to the tone alone, which elicits freezing behavior in the conditioned animal. This conditioned fear response depends on the long-term potentiation of the auditory response in neurons of the amygdala (Johansen et al. 2011). Both the synaptic changes and the persistence of the memory for learned fear require PKA, MAPKs, and the activation of CREB (Won and Silva 2008). Moreover, similar to mechanisms of NMDA receptor-dependent LTP, learned fear requires the enhanced trafficking of AMPA receptors to the synapses of amygdala neurons (Rumpel et al. 2005). In contrast to learned fear, when a tone predicts a period of safety when an animal is protected from the foot shock, there is a long-term depression of the auditory inputs to the amygdala (Rogan et al. 2005). Thus, learned fear and learned safety involve opposing changes in synaptic strength.

Eye-blink conditioning is produced by pairing a tone (the CS) with an aversive air puff to 
the eye (the US), resulting in a learned eye blink that is appropriately timed to the paired US (Thompson et al. 1983). Theoretical and experimental studies have proposed that the conditioning involves a relatively simple cerebellar circuit. Prior to learning, activation of cerebellar Purkinje neurons in response to the CS leads to an inhibition of neurons in the interpositus nucleus (one of the deep nuclei of the cerebellum), thereby inhibiting motor output. With conditioning there is a decrease in the Purkinje cell activity in response to the CS, resulting in disinhibition of the neurons of the interpositus nucleus, leading to eye blink. This model is consistent with findings that Purkinje cell activity can be reduced as a result of LTD at the excitatory parallel fiber synaptic input onto the Purkinje neurons (Ito 2001). This decrease in the strength of the parallel fibers occurs when the climbing fiber inputs to the cerebellum are activated in appropriate temporal proximity to parallel fiber activity. Thus, the Purkinje cells become less responsive to input, as a result of a down-regulation of AMPA receptors at the parallel fiber to Purkinje cell synapse.

The similarity between the changes in synaptic function and both procedural and declarative learning in the mammalian and invertebrate central nervous systems supports the view that alterations in synaptic strength represent an evolutionarily conserved general mechanism of memory formation. Moreover, studies of fear learning, eye-blink conditioning, and modifications of the vestibular-ocular reflex (Lisberger et al. 1987; Boyden et al. 2006), as well as habituation in Aplysia and crayfish, provide support for the role of both synaptic potentiation and synaptic depression as parallel mechanisms for memory storage.

\section{Synapse-Specific Local Protein Synthesis and Learning Networks}

There is now significant evidence from various forms of learning in a number of different species that the critical changes that store information in the brain occur at specific synapses within a circuit. The finding that long-term memory and synaptic plasticity involve changes in gene expression and therefore the nucleus of the cell-which is shared by all the synapses of the neuron-raises the question of how the gene products required for long-term memory influence the specific synapses that were altered to produce the immediate and short-term memory. Studies in both Aplysia (Martin et al. 1997) and the hippocampus (Frey and Morris 1997) suggest that the synaptic modifications associated with short-term plasticity leave a molecular mark or "tag" on the synapses that were modified. The presence of the synaptic tag allows those synapses to specifically capture and use newly synthesized gene products arriving from the nucleus to stabilize the initial changes produced with learning.

How is a synapse marked? Two distinct components of marking have been identified in Aplysia, one that requires PKA and initiates long-term synaptic plasticity and growth, and one that stabilizes long-term functional and structural changes at the synapse and requires (in addition to protein synthesis in the cell body) local protein synthesis at the synapse (Martin et al. 1997). Because mRNAs are made in the cell body, the need for the local translation of some mRNAs suggests that these mRNAs may be dormant before they reach the activated synapse. If that were true, one way of activating protein synthesis at the synapse would be to recruit a regulator of translation at the activated synapse that is capable of activating dormant mRNA. In Xenopus oocytes, maternal RNA is silent until activated by the cytoplasmic polyadenylation element binding protein (CPEB) (Richter 1999). In Aplysia a new isoform of CPEB (ApCPEB) with novel properties was found in neurons. Blocking this isoform at a marked (active) synapse prevented the maintenance but not the initiation of long-term synaptic facilitation (Si et al. 2003a,b). Indeed, blocking ApCPEB blocks memory days after it is formed. An interesting feature of this isoform of Aplysia CPEB is that its amino terminus resembles the prion domain of yeast prion proteins and endows it with similar self-sustaining properties. But unlike other prions, which are pathogenic, ApCPEB appears to be a functional prion. The active self-perpetuating form of the 
M. Mayford et al.

protein does not kill cells but rather has the important physiological function of maintaining long-term synaptic facilitation.

\section{THE EMERGENCE OF A SYSTEMS APPROACH TO MEMORY STORAGE}

The application of molecular and genetic tools and the use of simple systems have allowed us to test some of the foundational theories of Cajal and Hebb regarding the cellular mechanisms of learning. There are a number of commonalities that have been established across multiple species, such as:

1. Synaptic change is elicited by patterns of neuronal activity at critical points within a behavioral circuit.

2. Both increases and decreases in synaptic strength can contribute to behavioral plasticity.

3. Synaptic plasticity has similar temporal and molecular properties to behavioral learning, e.g., short- and long-term phases dependent on discrete signaling pathways.

4. Apparently different forms of learning use similar underlying cellular and molecular mechanisms.

One of the remaining challenges in rigorously testing some ideas in the mammalian nervous system is the problem of sparse encoding in distributed networks and the identification of the engram, the physical or functional memory trace present in a neural network posited by Lashley (1950). Although the fine-tuning of the hippocampal representation of the world and the sensitization of the gill-withdrawal reflex in Aplysia may recruit some of the same underlying molecular mechanisms, the changes in the hippocampus are dispersed throughout a large structure with no clear anatomical segregation. And although the hippocampus plays a critical role in memory, the formation of complex associations must involve activity in multiple brain areas. How can the dispersed circuits for a given specific memory or complex representation be isolated and functionally probed in the same manner as a reflex circuit in a simple system?

Several advances in the optical and molecular toolbox for circuit analysis in mammals are laying the foundation to answer this type of question. Advances in in vivo optical imaging techniques have enabled the visualization of plastic changes in neuronal properties associated with learning and memory (Hübener and Bonhoeffer 2010). Such changes can involve alterations in morphology of preexisting synapses, including the enlargement of dendritic spines (the sites of a pyramidal neuron's excitatory input) during LTP and spine shrinkage during LTD (Kasai et al. 2010). Additional structural changes may involve the growth of new synaptic connections, implied by the appearance of new dendritic spines following induction of synaptic plasticity. That such structural changes may contribute to learning and memory is supported by a recent study that reported the growth of new dendritic spines in motor cortex neurons following motor learning (Xu et al. 2009).

One area of rapid progress is in the introduction of genetically encoded molecules that allow the selective activation or suppression of the neurons in which they are expressed with light (Zhang et al. 2007a,b; Zhao et al. 2008; Airan et al. 2009). A great advantage of lightregulated channelrhodopsin or halorhodopsin is that they allow precise millisecond temporal control over action potential firing such that a genetically tagged group of neurons can be fired in a controlled pattern simply by patterning the light pulses. Also effective for turning neurons on or off are ligand-gated proteins with customized binding sites, such as the G-protein-coupled designer receptor (Alexander et al. 2009) and a chimeric ligand-gated ion channel, which are activated by an inert ligand (Magnus et al. 2011). These systems are allowing sparse but genetically defined neural cell types (e.g., inhibitory neurons) to be manipulated selectively within a background of many other functionally distinct cell types.

What defines a circuit in the mammalian brain? At one level there is a clear, developmentally controlled pattern of connectivity, for 
example, the hippocampal trisynaptic circuit or a cortical column. Although this canonical connectivity is clearly an important constraint on function, what is remarkable is that these circuits can represent so many different external events or encode a wide range of memories. Clearly, any individual neuron can participate in many different representations or memories, and at a deeper level a neural circuit is defined by what it represents. That is, we could define a circuit as all the neurons that are recruited during the recognition of an individual's home, or during the recollection of one's last holiday. How many neurons does it take to form a specific memory? How predetermined are these circuits? How are they modified during learning and differentially recruited during recall? And how can a new memory be formed through altered synaptic strength without overwriting a preexisting memory encoded in a neuron's synapses? Some new genetic techniques are beginning to probe these questions.

Competition between neurons is necessary for refining neural circuitry, but does it play a role in encoding memories in the adult brain? In studies of fear conditioning it was found that the introduction of excess or constitutively active CREB into a sparse subset of amygdala neurons caused those neurons to be specifically recruited to encode the memory to which the animals were subsequently trained (Han et al. 2007). Conversely, if such neurons are deleted after learning, that specific fear memory is blocked while other fear associations stay intact (Han et al. 2009). This study reveals that there is great flexibility in the particular group of neurons recruited to any given memory, at least in the amygdala, and that the resting state of the neuron governs the probability that it will be recruited.

Long-term memory requires transcriptional activity, and genes such as cfos, zif268, and arc are rapidly and transiently induced by high-frequency neural activity and have been used for many years to map brain activity patterns in rodents. By providing a genetic readout of patterns of neural activity, these genes provide the potential to obtain direct molecular control over ensembles of neurons based on their re- sponse to a given experience. In one study the cfos promoter was combined with elements of the TET regulatory system in transgenic mice to allow the introduction of a lac $Z$ marker into neurons activated with fear conditioning ( $\mathrm{Re}$ ijmers et al. 2007). The marker provided a longlasting record of brain activity during learning that could be compared to activity during recall. A partial reactivation of the neurons active during learning occurred, and the strength of the recalled memory was correlated with the degree of circuit reactivation. More importantly, this approach provides an opportunity to introduce any genetically encoded effector molecule into neurons based on their recent activity, providing the potential to study circuits based on the specific memory they encode.

Why are there so many forms of synaptic plasticity that differ in their mechanism of induction, time of persistence, and synaptic locus (Fig. 2)? An interesting insight into this question was provided by a theoretical study that approached the question of how a memory can persist in the face of the barrage of synaptic inputs and synaptic plasticity that a neuron experiences during an individual's lifetime. Although it was impossible to encode robust memories with a single form of plasticity, multiple forms of plasticity with distinct timescales of induction and persistence were able to yield persistent memory storage (Fusi et al. 2005). A challenge in the future will be to examine how the diverse array of plasticity mechanisms may indeed cooperate and interact to yield a unified mechanism of long-lasting yet ongoing memory storage.

\section{SUMMARY}

We now understand in considerable molecular detail the mechanisms underlying long-term synaptic plasticity and the importance that such plastic changes play in memory storage, across a broad range of species and forms of memory. One surprising finding is the remarkable degree of conservation of memory mechanisms in different brain regions within a species and across species widely separated by evolution. However, although it is now clear 
M. Mayford et al.

that long-term synaptic plasticity is a key step in memory storage, it is important to note that a simple enhancement in the efficacy of a synapse is not sufficient to store a complex memory. Rather, changes in synaptic function must occur within the context of an ensemble of neurons to produce a specific alteration in information flow through a neural circuit. With the recent development of powerful genetic tools, it may soon be possible to meet the daunting challenge of visualizing and manipulating such changes in neural circuitry. A second important challenge is to understand how the basic processes of memory storage are altered with age or disease, including Alzheimer's disease. There is now compelling evidence that defects in memory storage result from pathological changes in the fundamental mechanisms underlying longterm synaptic plasticity. Thus, it becomes of critical importance to understand in sufficient detail both the basic mechanisms of memory storage and the changes that take place in disease to design specific compounds that can be used to restore cognitive function.

\section{REFERENCES}

* Reference is also in this collection.

Abel T, Nguyen PV, Barad M, Deuel TA, Kandel ER, Bourtchouladze R. 1997. Genetic demonstration of a role for PKA in the late phase of LTP and in hippocampus-based long-term memory. Cell 88: 615-626.

Abel T, Martin KC, Bartsch D, Kandel ER. 1998. Memory suppressor genes: Inhibitory constraints on the storage of long-term memory. Science 279: 338-341.

Airan RD, Thompson KR, Fenno LE, Bernstein H, Deisseroth K. 2009. Temporally precise in vivo control of intracellular signaling. Nature 458: 1025-1029.

Alberini CM, Ghirardi M, Metz R, Kandel ER. 1994. C/EBP is an immediate-early gene required for the consolidation of long-term facilitation in Aplysia. Cell 76: 10991114.

Alexander GM, Rogan SC, Abbas AI, Armbruster BN, Pei Y, Allen JA, Nonneman RJ, Hartmann J, Moy SS, Nicolelis MA, et al. 2009. Remote control of neuronal activity in transgenic mice expressing evolved G protein-coupled receptors. Neuron 63: 27-39.

Alkon DL. 1974. Associative training of Hermissenda. J Gen Physiol 64: 70-84.

Bacskai BJ, Hochner B, Mahaut-Smith M, Adams SR, Kaang BK, Kandel ER, Tsien RY. 1993. Spatially resolved dynamics of cAMP and protein kinase A subunits in Aplysia sensory neurons. Science 260: 222-226.
Bailey CH, Chen M. 1983. Morphological basis of long-term habituation and sensitization in Aplysia. Science 220: 91-93.

Bailey CH, Chen M. 1988a. Long-term memory in Aplysia modulates the total number of varicosities of single identified sensory neurons. Proc Natl Acad Sci 85: 2373-2377.

Bailey CH, Chen M. 1988b. Long-term sensitization in Aplysia increases the number of presynaptic contacts onto the identified gill motor neuron L7. Proc Natl Acad Sci 85: 9356-9359.

Bailey CH, Kandel ER. 1993. Structural changes accompanying memory storage. Annu Rev Physiol 55: 397-426.

Bailey CH, Barco A, Hawkins RD, Kandel ER. 2008. Molecular studies of learning and memory in Aplysia and the hippocampus: Comparative analysis of implicit and explicit memory storage. In Learning and memory: A comprehensive reference (ed. JH Byrne), pp. 11-29. Elsevier, Oxford.

Bartsch D, Ghirardi M, Skehel PA, Karl KA, Herder SP, Chen M, Bailey CH, Kandel ER. 1995. Aplysia CREB2 represses long-term facilitation: Relief of repression converts transient facilitation into long-term functional and structural change. Cell 83: 979-992.

Bayazitov IT, Richardson RJ, Fricke RG, Zakharenko SS. 2007. Slow presynaptic and fast postsynaptic components of compound long-term potentiation. J Neurosci 27: 11510-11521.

Bliss TV, Collingridge GL. 1993. A synaptic model of memory: Long-term potentiation in the hippocampus. Nature 361: 31-39.

Bliss TVP, Lomo T. 1973. Long-lasting potentiation of synaptic transmission in the dentate area of the anaesthetized rabbit following stimulation of the perforant path. $J$ Physiol 232: 331-356.

Bolshakov VY, Siegelbaum S. 1994. Postsynaptic induction and presynaptic expression of hippocampal long-term depression. Science 264: 1148-1152.

Bourtchuladze R, Frenguelli B, Blendy J, Cioffi D, Schutz G, Silva AJ. 1994. Deficient long-term memory in mice with a targeted mutation of the cAMP-responsive elementbinding protein. Cell 79: 59-68.

Boyden ES, Katoh A, Pyle JL, Chatila TA, Tsien RW, Raymond JL. 2006. Selective engagement of plasticity mechanisms for motor memory storage. Neuron 51: 823-834.

Brunelli M, Castellucci V, Kandel ER. 1976. Synaptic facilitation and behavioral sensitization in Aplysia: Possible role of serotonin and cyclic AMP. Science 194: 11781181.

Byers D, Davis RL, Kiger JA. 1981. Defect in cyclic AMP phosphodiesterase due to the dunce mutation of learning in Drosophila melanogaster. Nature 289: 79-81.

Cajal SR. 1894. La fine structure des centres nerveux. Proc $R$ Soc Lond 55: 444-468.

Carew TJ, Sahley CJ. 1986. Invertebrate learning and memory: From behavior to molecules. Annu Rev Neurosci 9: 435-487.

Carew TJ, Pinsker HM, Kandel ER. 1972. Long-term habituation of a defensive withdrawal reflex in Aplysia. Science 175: $451-454$.

Carew TJ, Castelucci VF, Byrne JH, Kandel ER. 1979. Quantitative analysis of relative contribution of central and 
peripheral neurons to gill-withdrawal reflex in Aplysia californica. Neurophysiol 42: 497-509.

Carroll RC, Beattie EC, Xia H, Lüscher C, Altschuler Y, Nicholl RA, Malenka RC, von Zastrow M. 1999. Dynamin-dependent endocytosis of ionotropic glutamate receptors. Proc Natl Acad Sci 96: 14112-14117.

Castellucci VF, Kandel ER. 1974. A quantal analysis of the synaptic depression underlying habituation of the gillwithdrawal reflex in Aplysia. Proc Natl Acad Sci 71: 5004-5008.

Castellucci V, Kandel ER. 1976. Presynaptic facilitation as a mechanism for behavioral sensitization in Aplysia. Science 194: 1176-1178.

Castellucci V, Pinsker H, Kupfermann I, Kandel ER. 1970. Neuronal mechanisms of habituation and dishabituation of the gill-withdrawal reflex in Aplysia. Science 167: $1745-1748$.

Castellucci VF, Carew TJ, Kandel ER. 1978. Cellular analysis of long-term habituation of the gill-withdrawal reflex of Aplysia californica. Science 202: 1306-1308.

Dash PK, Hochner B, Kandel ER. 1990. Injection of cAMPresponsive element into the nucleus of Aplysia sensory neurons blocks long-term facilitation. Nature 345: $718-721$.

Davis M, Hitchcock JM, Bowers MB, Berridge CW, Melia KR, Roth RH. 1994. Stress-induced activation of prefrontal cortex dopamine turnover: Blockade by lesions of the amygdala. Brain Res 664: 207-210.

Deyo RA, Straube KT, Disterhoft JF. 1989. Nimodipine facilitates associative learning in aging rabbits. Science 243: 809-811.

Dolphin AC, Errington ML, Bliss TV. 1982. Long-term potentiation of the perforant path in vivo is associated with increased glutamate release. Nature 297: 496-498.

Drain P, Folkers E, Quinn WG. 1991. cAMP-dependent protein kinase and the disruption of learning in transgenic flies. Neuron 6: 71-82.

Dudai Y, Jan YN, Byers D, Quinn WG, Benzer S. 1976. dunce, a mutant of Drosophila deficient in learning. Proc Natl Acad Sci 73: 1684-1688.

Duerr JS, Quinn WG. 1982. Three Drosophila mutations that block associative learning also affect habituation and sensitization. Proc Natl Acad Sci 79: 3646-3650.

Emptage NJ, Reid CA, Fine A, Bliss TV. 2003. Optical quantal analysis reveals a presynaptic component of LTP at hippocampal Schaffer-associational synapses. Neuron 38: $797-804$.

Enoki R, Hu YL, Hamilton D, Fine A. 2009. Expression of long-term plasticity at individual synapses in hippocampus is graded, bidirectional, and mainly presynaptic: Optical quantal analysis. Neuron 62: 242-253.

Flexner JB, Flexner LB, Stellar E. 1963. Memory in mice as affected by intracerebral puromycin. Science 141: 57-59.

Frey U, Morris RG. 1997. Synaptic tagging and long-term potentiation. Nature 385: 533-536.

Frey U, Huang YY, Kandel ER. 1993. Effects of cAMP simulate a late stage of LTP in hippocampal CA1 neurons. Science 260: 1661-1664.

Frost WN, Kandel ER. 1995. Structure of the network mediating siphon-elicited siphon withdrawal in Aplysia. J Neurophysiol 73: 2413-2427.
Fusi S, Drew PJ, Abbott LF. 2005. Cascade models of synaptically stored memories. Neuron 45: 599-611.

Fyhn M, Molden S, Witter MP, Moser EI, Moser MB. 2004. Spatial representation in the entorhinal cortex. Science 305: $1258-1264$.

Gelperin A. 1975. Rapid food-aversion learning by a terrestrial mollusk. Science 189: 567-570.

Ghirardi M, Abel T, Alberini C, Huang Y, Nguyen P, Kandel ER. 1995. Steps toward a molecular definition of memory consolidation. In Memory distortion (ed. DL Schacter), pp. 298-325. Harvard University Press, Cambridge, MA.

Grant SG, O’Dell TJ, Karl KA, Stein PL, Soriano P, Kandel ER. 1992. Impaired long-term potentiation, spatial learning, and hippocampal development in fyn mutant mice. Science 258: 1903-1910.

Grover LM, Teyler TJ. 1990. Two components of long-term potentiation induced by different patterns of afferent activation. Nature 347: 477-479.

Hafting T, Fyhn M, Molden S, Moser MB, Moser EI. 2005. Microstructure of a spatial map in the entorhinal cortex. Nature 436: 801-806.

Han J-H, Kushner SA, Yiu AP, Cole CJ, Matynia A, Brown RA, Neve RL, Guzowski JF, Silva AJ, Josselyn SA. 2007. Neuronal competition and selection during memory formation. Science 316: 457-460.

Han J-H, Kushner SA, Yiu AP, Hsiang H-L, Buch T, Waisman A, Bontempi B, Neve RL, Frankland PW, Josselyn SA. 2009. Selective erasure of a fear memory. Science 323: 1492-1496.

Hawkins RD, Kandel ER. 1984. Is there a cell-biological alphabet for simple forms of learning? Psychol Rev 91: 375-391.

Hawkins RD, Castellucci VF, Kandel ER. 1981. Interneurons involved in mediation and modulation of gill-withdrawal reflex in Aplysia. I. Identification and characterization. $J$ Neurophysiol 45: 304-314.

Hegde AN, Inokuchi K, Pei W, Casadio A, Ghirardi M, Chain DG, Martin KC, Kandel ER, Schwartz JH. 1997. Ubiquitin C-terminal hydrolase is an immediate-early gene essential for long-term facilitation in Aplysia. Cell 89: $115-126$.

Hoffman DA, Sprengel R, Sakmann B. 2002. Molecular dissection of hippocampal theta-burst pairing potentiation. Proc Natl Acad Sci 99: 7740-7745.

Huang Y-Y, Kandel ER, Varshavsky L, Brandon EP, Idzerda RL, McKnight GS, Bourtchouladze R. 1995. A genetic test of the effects of mutations in PKA on mossy fiber LTP and its relation to spatial and contextual learning. Cell 83: 1211-1222.

Hübener M, Bonhoeffer T. 2010. Searching for engrams. Neuron 67: 363-371.

Ito M. 2001. Cerebellar long-term depression: Characterization, signal transduction, and functional roles. Physiol Rev 81: 1143-1195.

Johansen JP, Cain CK, Ostroff LE, LeDoux JE. 2011. Molecular mechanisms of fear learning and memory. Cell 147: 509-524.

Kandel ER. 1976. Cellular basis of behavior: An introduction to behavioral neurobiology. W.H. Freeman, San Francisco. 
M. Mayford et al.

Kandel ER. 2001. The molecular biology of memory storage: A dialogue between genes and synapses. Science 294: $1030-1038$.

Kandel ER, Spencer WA. 1968. Cellular neurophysiological approaches in the study of learning. Physiol Rev 48: 65-134.

Kasai H, Fukuda M, Watanabe S, Hayashi-Takagi A, Noguchi J. 2010. Structural dynamics of dendritic spines in memory and cognition. Trends Neurosci 33: 121-129.

Kauer JA, Malenka RC, Nicoll RA. 1988. A persistent postsynaptic modification mediates long-term potentiation in the hippocampus. Neuron 10: 911-917.

Keleman K, Krüttner S, Alenius M, Dickson BJ. 2007. Function of the Drosophila CPEB protein Orb2 in long-term courtship memory. Nat Neurosci 10: 1587-1593.

Kentros C, Hargreaves E, Hawkins RD, Kandel ER, Shapiro M, Muller RV. 1998. Abolition of long-term stability of new hippocampal place cell maps by NMDA receptor blockade. Science 280: 2121-2126.

Krasne FB. 1969. Excitation and habituation of the crayfish escape reflex: The depolarizing response in lateral giant fibres of the isolated abdomen. J Exp Biol 50: 29-46.

Lashley K. 1950. In search of the engram. Symp Soc Exp Biol 4: 454-482.

LeDoux JE. 1995. Emotion: Clues from the brain. Annu Rev Psychol 46: 209-235.

LeDoux JE. 1996. The emotional brain: The mysterious underpinnings of emotional life. Simon and Schuster, New York.

Lisberger SG, Morris EJ, Tychsen L. 1987. Visual motion processing and sensory motor integration for smooth pursuit eye movements. Annu Rev Neurosci 10: 97-129.

* Lüscher C, Malenka RC. 2012. NMDA receptor-dependent long-term potentiation and long-term depression (LTP/ LTD). Cold Spring Harb Perspect Biol doi: 10.1101/ cshperspect.a005710.

Lynch G, Baudry M. 1984. The biochemistry of memory: A new and specific hypothesis. Science 224: 1057-1063.

Lynch G, Halpain S, Baudry M. 1982. Effects of high-frequency synaptic stimulation on glumate receptor binding studied with a modified in vitro hippocampal slice preparation. Brain Res 244: 101-111.

Lynch G, Larson J, Kelso S, Barrionuevo G, Schottler F. 1983. Intracellular injections of EGTA block induction of hippocampal long-term potentiation. Nature 305: 719-721.

Magee JC, Johnston D. 1997. A synaptically controlled, associative signal for Hebbian plasticity in hippocampal neurons. Science 275: 209-213.

Magnus CJ, Lee PH, Atasoy D, Su HH, Looger LL, Sternson SM. 2011. Chemical and genetic engineering of selective ion channel-ligand interactions. Science 333: 1292-1296.

Malenka RC, Kauer JA, Zucker RS, Nicoll RA. 1988. Postsynaptic calcium is sufficient for potentiation of hippocampal synaptic transmission. Science 242: 81-84.

Malenka RC, Kauer JA, Perkel DJ, Mauk MD, Kelly PT, Nicoll RA, Waxham MN. 1989. An essential role for postsynaptic calmodulin and protein kinase activity in longterm potentiation. Nature 340: 554-557.

Malinow R, Tsien RW. 1990. Presynaptic enhancement shown by whole-cell recordings and long-term potentiation in hippocampal slices. Nature 346: 177-180.
Malinow R, Madison DV, Tsien RW. 1988. Persistent protein kinase activity underlying long-term potentiation. $\mathrm{Na}$ ture 335: 820-824.

Malinow R, Schulman H, Tsien RW. 1989. Inhibition of postsynaptic PKC or CaMKII blocks induction but not expression of LTP. Science 245: 862-866.

Markram H, Lübke J, Frotscher M, Sakmann B. 1997. Regulation of synaptic efficacy by coincidence of postsynaptic APs and EPSPs. Science 275: 213-215.

Marr D. 1971. Simple memory: A theory for archicortex. Philos Trans R Soc Lond B Biol Sci 262: 23-81.

Martin KC, Casadio A, Zhu H, Yaping E, Rose JC, Chen M, Bailey CH, Kandel ER. 1997. Synapse-specific, long-term facilitation of Aplysia sensory to motor synapses: A function for local protein synthesis in memory storage. Cell 91: 927-938.

Mayford M, Bach ME, Huang YY, Wang L, Hawkins RD, Kandel ER. 1996. Control of memory formation through regulated expression of a CaMKII transgene. Science 274: $1678-1683$.

McDonald RJ, White NM. 1993. A triple dissociation of memory systems: Hippocampus, amygdala, and dorsal striatum. Behav Neurosci 107: 3-22.

McHugh TJ, Jones MW, Quinn JJ, Bathasar N, Coppari R, Elmquist JK, Lowell BB, Fanselow MS, Wilson MA, Tonegawa S. 2007. Denate gyrus NMDA receptors mediate rapid pattern separation in the hippocampal network. Science 317: 94-99.

McKernan MG, Shinnick-Gallagher P. 1997. Fear conditioning induces a lasting potentiation of synaptic currents in vitro. Nature 390: 607-611.

Menzel R, Erber J. 1978. Learning and memory in bees. Sci Am 239: 80-87.

Morris RG, Garrud P, Rawlins JN, O’Keefe J. 1982. Place navigation impaired in rats with hippocampal lesions. Nature 297: 681-683.

Morris RG, Anderson E, Lynch GS, Baudry M. 1986. Selective impairment of learning and blockade of long-term potentiation by an $N$-methyl-D-aspartate receptor antagonist, AP5. Nature 319: 774-776.

Mpitsos GJ, Davis WJ. 1973. Learning: Classical and avoidance conditioning the mollusk Pleurobranchaea. Science 180: $317-320$.

Nicoll RA, Tomita S, Bredt D. 2006. Auxiliary subunits assist AMPA-type glutamate receptors. Science 3: 1253-1256.

Nowak L, Bregestovski P, Ascher P, Herbet A, Prochiantz A. 1984. Magnesium gates glutamate-activated channels in mouse central neurones. Nature 307: 462-465.

O’Dell TJ, Kandel ER, Grant SG. 1991. Long-term potentiation in the hippocampus is blocked by tyrosine kinase inhibitors. Nature 353: 558-560.

O’Keefe J, Dostrovsky J. 1971. The hippocampus as a spatial map. Preliminary evidence from unit activity in the freely moving rat. Brain Res 34: 171-175.

O'Keefe J, Nadel L. 1978. The hippocampus as a cognitive map. Clarendon Press, Oxford.

Park M, Penick EC, Edwards JG, Kauer JA, Ehlers MD. 2004. Recycling endosomes supply AMPA receptors for LTP. Science 305: 1972-1975. 
Pinsker HM, Hening WA, Carew TJ, Kandel ER. 1973. Longterm sensitization of a defensive withdrawal reflex in Aplysia. Science 182: 1039-1042.

Quinn WG, Harris WA, Benzer S. 1974. Conditioned behavior in Drosophila melanogaster. Proc Natl Acad Sci 71: $708-712$.

Reid CA, Fabian-Fine R, Fine A. 2001. Postsynaptic calcium transients evoked by activation of individual hippocampal mossy fiber synapses. J Neurosci 21: 2206-2214.

Reid CA, Dixon DB, Takahashi M, Bliss TV, Fine A. 2004 Optical quantal analysis indicates that long-term potentiation at single hippocampal mossy fiber synapses is expressed through increased release probability, recruitment of new release sites, and activation of silent synapses. J Neurosci 24: 3618-3626.

Reijmers LG, Perkins BL, Matsuo NH, Mayford M. 2007. Localization of a stable neural correlate of associative memory. Science 317: 1230-1233.

Reisel D, Bannerman DM, Schmitt WB, Deacon RM, Flint J, Borchardt T, Seeburg PH, Rawlins JN. 2002. Spatial memory dissociations in mice lacking GluR1. Nat Neurosci 5: $868-873$.

Rescorla RA, Wagner AR. 1972. A theory of Pavlovian conditioning: Variations in the effectiveness of reinforcement and nonreinforcement. In Classical conditioning II: Current research and theory (ed. AH Black, WF Prokasy), pp. 64-99. Appleton-Century-Crofts, New York.

Ressler KJ, Rothbaum BO, Tannenbaum L, Anderson P, Graap K, Zimand E, Hodges L, Davis M. 2004. Cognitive enhancers as adjuncts to pscyhotherapy: Use of D-cycloserine in phobic individuals to facilitate extinction of fear. Arch Gen Psychiatry 61: 1136-1144.

Richter JD. 1999. Cytoplasmic polyadenylation in development and beyond. Microbiol Mol Biol Rev 63: 446-456.

Rogan MT, Stäubli UV, LeDoux JE. 1997. Fear conditioning induces associative long-term potentiation in the amygdala. Nature 390: 604-607.

Rogan MT, Leon KS, Perez DL, Kandel ER. 2005. Distinct neural signatures for safety and danger in the amygdala and striatum of the mouse. Neuron 46: 309-320.

Routtenberg A. 1986. Synaptic plasticity and protein kinase C. Prog Brain Res 69: 211-234.

Rumpel S, LeDoux J, Zador A, Malinow R. 2005. Postsynaptic receptor trafficking underlying a form of associative learning. Science 308: 83-88.

Ryan TA, Ziv NE, Smith SJ. 1996. Potentiation of evoked vesicle turnover at individually resolved synaptic boutons. Neuron 17: 125-134.

Sanderson DJ, Good MA, Skelton K, Sprengel R, Seeburg PH, Rawlins JN, Bannerman DM. 2009. Enhanced longterm and impaired short-term spatial memory in GluAl AMPA receptor subunit knockout mice: Evidence for a dual-process memory model. Learn Mem 16: 379-386.

Schachter DL, Tulving E. 1994. What are the memory systems of 1994? In Memory systems (ed. DL Schacter, E Tulving), pp. 1-38. MIT Press, Cambridge, MA.

Scoville WB, Milner B. 1957. Loss of recent memory after bilateral hippocampal lesions. J Neurol Neurosurg Psychiatry 20: $11-21$.

Serrano P, Friedman EL, Kenney J, Taubenfeld SM, Zimmerman JM, Hanna J, Alberini C, Kelley AE, Maren S, Rudy
JW, et al. 2008. PKM $\zeta$ maintains spatial, instrumental, and classically conditioned long-term memories. PloS Biol 6: 2698-2706.

Shankar S, Teyler TJ, Robbins N. 1998. Aging differentially alters forms of long-term potentiation in rat hippocampal area CA1. J Neurophysiol 79: 334-341.

Shi SH, Hayashi Y, Petralia RS, Zaman SH, Wenthold RJ, Svoboda K, Malinow R. 1999. Rapid spine delivery and redistribution of AMPA receptors after synaptic NMDA receptor activation. Science 284: 1811-1816.

Shimshek DR, Jensen V, Celikel T, Geng Y, Schupp B, Bus T, Mack V, Marx V, Hvalby Ø, Seeburg PH, Sprengel R. 2006. Forebrain-specific glutamate receptor B deletion impairs spatial memory but not hippocampal field long-term potentiation. J Neurosci 26: 8428-8440.

Si K, Lindquist S, Kandel ER. 2003. A neuronal isoform of the Aplysia CPEB has prion-like properties. Cell 115: 879-891.

Silva AJ, Paylor R, Wehner JM, Tonegawa S. 1992a. Impaired spatial learning in $\alpha$-calcium-calmodulin kinase II mutant mice. Science 257: 206-211.

Silva AJ, Stevens CF, Tonegawa S, Wang Y. 1992b. Deficient hippocampal long-term potentiation in $\alpha$-calciumcalmodulin kinase II mutant mice. Science 257: $201-$ 206.

Spencer W, Thompson RF, Nielson DR. 1966. Decrement of ventral root electrotonus and intracellularly recorded PSPs produced by iterated cutaneous afferent volleys. J Neurophysiol 29: 253-274.

Squire LR. 1992. Memory and the hippocampus: A synthesis from findings with rats, monkeys, and humans. Psychol Rev 99: 195-231.

Squire LR, Stark CE, Clark RE. 2004. The medial temporal lobe. Annu Rev Neurosci 27: 279-306.

Sutton MA, Carew TJ. 2000. Parallel molecular pathways mediate expression of distinct forms of intermediateterm facilitation at tail sensory-motor synapses in Aplysia. Neuron 26: 219-231.

Theis M, Si K, Kandel E. 2003. Two previously undescribed members of the mouse CPEB family of genes and their inducible expression in the principle cell layers of the hippocampus. Proc Natl Acad Sci 100: 9602-9607.

Thompson RF, McCormick DA, Lavond DG, Clark GA, Kettner RE, Mauk MD. 1983. Initial localization of the memory trace for a basic form of associative learning. Prog Psychobiol Physiol Psychol 10: 167-196.

Tsien JZ, Chen DF, Gerber D, Tom C, Mercer EH, Anderson DJ, Mayford M, Kandel ER, Tonegawa S. 1996a. Subregion and cell type-restricted gene knockout in mouse brain. Cell 87: 1317-1326.

Tsien JZ, Huerta PT, Tonegawa S. 1996b. The essential role of hippocampal CA1 NMDA receptor-dependent synaptic plasticity in spatial memory. Cell 87: 1327-1338.

Tsvetkov E, Carlezon WA, Benes FM, Kandel ER, Bolshakov VY. 2002. Fear conditioning occludes LTP-induced presynaptic enhancement of synaptic transmission in the cortical pathway to the lateral amygdala. Neuron 34: 289-300.

Waddell S, Quinn WG. 2001. Flies, genes, and learning. Annu Rev Neurosci 24: 1283-1309. 
M. Mayford et al.

Watkins JC, Jane DE. 2006. The glutamate story. Brit J Pharmacol 147: S100-108.

Westbrook G, Mayer M, Guthrie P. 1984. Voltage-dependent block by $\mathrm{Mg}^{2+}$ of NMDA responses in spinal cord neurones. Nature 309: 261-263.

Willows AO, Hoyle G. 1969. Neuronal network triggering a fixed action pattern. Science 166: 1549-1551.

Winder DG, Mansuy IM, Osman M, Moallem TM, Kandel ER. 1998. Genetic and pharmacological evidence for a novel, intermediate phase of long-term potentiation suppressed by calcineurin. Cell 92: 25-37.

Won J, Silva AJ. 2008. Molecular and cellular mechanisms of memory allocation in neuronetworks. Neurobiol Learn Mem 89: 285-292.

Woodside BL, Borroni AM, Hammonds MD, Teyler TJ. 2004. NMDA receptors and voltage-dependent calcium channels mediate different aspects of acquisition and retention of a spatial memory task. Neurobiol Learn Mem 81: 105-114.

Xu T, Yu X, Perlik AJ, Tobin WF, Zweig JA, Tennant K, Jones T, Zuo Y. 2009. Rapid formation and selective stabilization of synapses for enduring motor memories. Nature 462: 915-919.

Yin JCP, Wallach JHS, Del Vecchio M, Wilder EL, Zhou H, Quinn WG, Tully T. 1994. Induction of a dominant negative CREB transgene specifically blocks long-term memory in Drosophila. Cell 79: 49-58.
Zakharenko SS, Zablow L, Siegelbaum SA. 2001. Visualization of changes in presynaptic function during long-term synaptic plasticity. Nat Neurosci 4: 711-717.

Zakharenko SS, Patterson SL, Dragatsis I, Zeitlin SO, Siegelbaum SA, Kandel ER, Morozov A. 2003. Presynaptic BDNF required for a presynaptic but not postsynaptic component of LTP at hippocampal CA1-CA3 synapses. Neuron 39: 975-990.

Zamanillo D, Sprengel R, Hvalby O, Jensen V, Burnashev N, Rozov A, Kaiser KM, Köster HJ, Borchardt T, Worley P, et al. 1999. Importance of AMPA receptors for hippocampal synaptic plasticity but not for spatial learning. Science 284: 1805-1811.

Zhang F, Aravanis AM, Adamantidis A, deLecea L, Deisseroth K. 2007a. Circuit-breakers: Optical technologies for probing neural signals and systems. Nat Rev Neurosci 8: 577-581.

Zhang F, Wang LP, Brauner M, Liewald JF, Kay K, Watzke N, Wood PG, Bamberg E, Nagel G, Gottschalk A, et al. 2007b. Multimodal fast optical interrogation of neural circuitry. Nature 446: 633-639.

Zhao S, Cunha C, Zhang F, Liu Q, Gloss B, Deisseroth K, Augustine GJ, Feng G. 2008. Improved expression of halorhodopsin for light-induced silencing of neuronal activity. Brain Cell 36: 141-154.

Zucker RS, Kennedy D, Selverston AI. 1971. Neuronal circuit mediating escape responses in crayfish. Science 173: 645-650. 


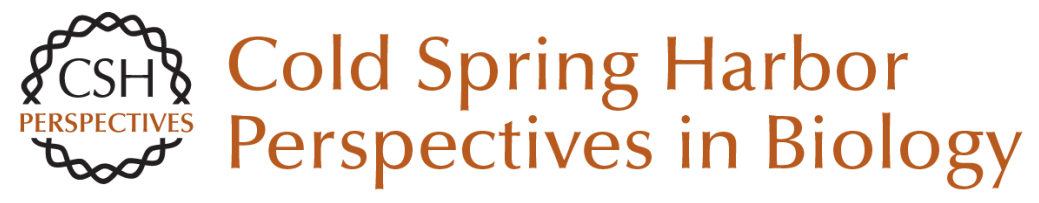

\section{Synapses and Memory Storage}

Mark Mayford, Steven A. Siegelbaum and Eric R. Kandel

Cold Spring Harb Perspect Biol 2012; doi: 10.1101/cshperspect.a005751 originally published online April 10, 2012

\section{Subject Collection The Synapse}

Studying Signal Transduction in Single Dendritic Spines Ryohei Yasuda

Synaptic Vesicle Pools and Dynamics AbdulRasheed A. Alabi and Richard W. Tsien

Synapses and Memory Storage Mark Mayford, Steven A. Siegelbaum and Eric R. Kandel

Synapses and Alzheimer's Disease Morgan Sheng, Bernardo L. Sabatini and Thomas C. Südhof

\section{Synaptic Cell Adhesion}

Markus Missler, Thomas C. Südhof and Thomas Biederer

Synaptic Dysfunction in Neurodevelopmental Disorders Associated with Autism and Intellectual Disabilities

Huda Y. Zoghbi and Mark F. Bear

The Postsynaptic Organization of Synapses Morgan Sheng and Eunjoon Kim

Presynaptic LTP and LTD of Excitatory and Inhibitory Synapses

Pablo E. Castillo
Synaptic Vesicle Endocytosis

Yasunori Saheki and Pietro De Camilli

Short-Term Presynaptic Plasticity Wade G. Regehr

NMDA Receptor-Dependent Long-Term

Potentiation and Long-Term Depression

(LTP/LTD) Christian Lüscher and Robert C. Malenka

Ultrastructure of Synapses in the Mammalian

Brain Kristen M. Harris and Richard J. Weinberg

Calcium Signaling in Dendritic Spines Michael J. Higley and Bernardo L. Sabatini

Synaptic Neurotransmitter-Gated Receptors Trevor G. Smart and Pierre Paoletti

Synaptic Vesicle Exocytosis

Thomas C. Südhof and Josep Rizo

Vesicular and Plasma Membrane Transporters for Neurotransmitters

Randy D. Blakely and Robert H. Edwards

For additional articles in this collection, see http://cshperspectives.cshlp.org/cgi/collection/

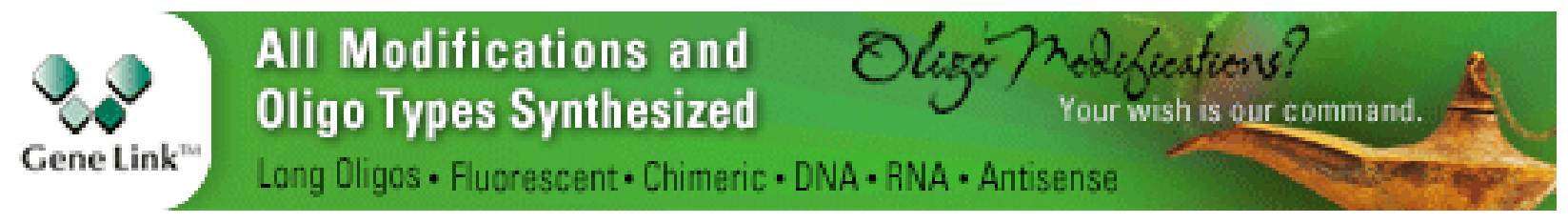

